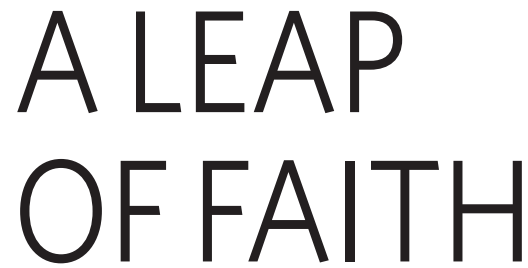

How much can geometry and mathematics reveal about paintings? How far should hidden meanings be trusted in art? Jo Marchant investigates the latest, and possibly most controversial, interpretation of a Renaissance masterpiece.

T he scene is eerily still. In the distance, a half-naked figure is being whipped, watched over by an impassive ruler. In the foreground stand three expressionless men, more richly dressed, apparently unaware of the violence behind them and even of each other. The scene is vivid and lifelike, yet it has a dream-like quality. Nobody speaks. Nobody catches anyone else's eye. No wonder this painting has been described as the pictorial equivalent of silence.

This is The Flagellation, painted by Piero della Francesca in fifteenth-century Italy and reproduced in full on the cover of this issue. An accomplished mathematician, Piero is known for his stunning use of perspective (just look at the tiled floor), which has helped make this painting one of the most famous masterpieces of the Renaissance. But that is not its only fascination.

Piero planned his paintings down to the last detail, and this meticulously executed scene contains several mysteries, particularly the identities of the three men on the right. Countless attempts have been made to name them. "The interpretation of The Flagellation is one of those causes célèbres, like The Last Supper," says Martin Kemp, an art historian at Oxford University, UK, who has written on Piero's paintings. "It's in that league as a magnet for theories.”

A leading historian of science now believes he has historical evidence that can identify all the mysterious figures at a stroke. David King, director of the Institute for the History of Science in Frankfurt, Germany, says that his interpretation reveals new mathematical features that push our understanding of Piero's geometrical

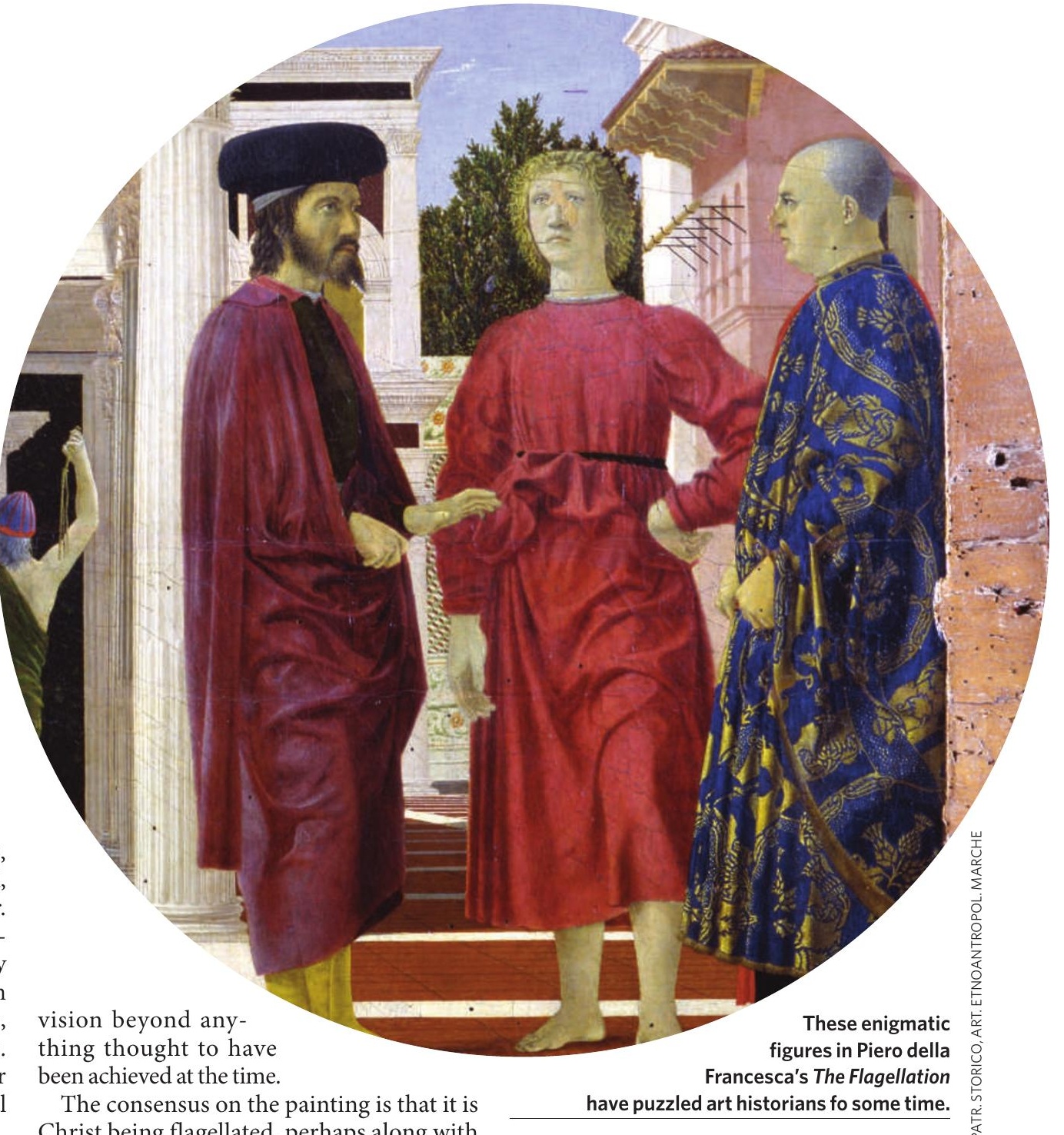

Christ being flagellated, perhaps along with the Church, or the Byzantine Empire, which fell to the Ottoman Turks in 1453. The ruler sitting on the throne of Pontius Pilate and watching over the punishment seems to be the fifteenth-century Byzantine emperor Ioannis VIII, identified by his characteristic red hat. The man in the turban with his back to us has been identified as either King Herod or the Ottoman sultan, Mehmet II. But the identity and purpose of the figures on the right has been the subject of wild speculation.

There is no documentary evidence on who commissioned the painting, why, or even when (though historians think it was late in Piero's career, around 1460). The painter left just one tantalizing clue: according to a report in 1839, an integral frame, now lost, bore the painting's original title, Convenerunt in unum, or "They came together in one."

Controversially, King's smoking gun is not a manuscript but a scientific instrument, and its meaning is buried deep within a mind-boggling code. If he is right, the painting can be seen as one of the most ingenious hidden messages of all time. Although some scholars cautiously welcome his ideas, art historians are notably less impressed. King pushes his theory to its limits, and his bullish claims have angered some.

King thinks the reluctance to accept his work results from a culture clash between mathematical expertise and art history. Kemp, who has a scientific background, acknowledges that when it comes to studying painters such as Piero, art historians could do with a better understanding of mathematics. "The maths isn't that hard," he says. "If you can do Euclid you can do Piero."

Art historians counter that King has been too quick to disregard criteria they have developed to guide legitimate enquiry into such enigmatic artworks. "It's not a case of keeping outsiders out," Kemp agrees. "David King is a major historian of scientific instruments. It is a question of how far his huge expertise is transferable without a good deal of caution."

\section{Material evidence}

King's interest in this story began with a fifteenth-century astrolabe made in Vienna. Now superseded by modern instruments, astrolabes were used by Renaissance astronomers for time-telling, navigation and predicting the movements of the heavens. This particular astrolabe is modest, just 11.5 centimetres across, 
but it has an unusual inscription on the back (see opposite).

Roughly translated, the inscription says "Under the protection of the divine Bessarion, said to come from the axis, I arise as the work of Johannes in Rome in 1462." (The inscription is reproduced at larger size in the graphic overleaf.) The couplet suggests that the astrolabe was a gift from Johannes Regiomontanus, a young astronomer and instrument-maker, to his mentor Bessarion. The gift is dated to 1462, roughly the time that Piero painted The Flagellation.

\section{Master and pupil}

Johannes (Ioannis) Bessarion was a Greek cardinal who famously switched churches to became a cardinal in Rome, following failed attempts to unify the Eastern and Western Churches in 1439. In Rome, Bessarion campaigned for a crusade to fight off the advancing Ottoman Turks, and when Constantinople, the centre of the Eastern Church, fell to the Turks in 1453 , the cardinal was devastated.

A learned scholar, Bessarion brought hundreds of Greek manuscripts to Italy to be translated into Latin, helping to kickstart the Renaissance there. Bessarion met Regiomontanus in Vienna in 1460, and persuaded the youth to come to Rome as his student. King believes that Bessarion at the time had in his possession a famous Byzantine astrolabe made in 1062 with a Greek inscription, which King has also studied, and that Bessarion showed it to Regiomontanus while in Vienna. Before leaving for Rome, Regiomontanus made Bessarion another astrolabe as a gift, inscribed with a personal message.

Flaws in the inscribed couplet have intrigued King for years. The metre is almost — but not quite - perfect. The letters are oddly spaced, with some squeezed together and others stretched apart. And the name 'Ioannis' is split over two lines. Regiomontanus was a renowned poet and instrument-maker - so why would he have let pass such imperfections in a gift to his beloved mentor?

These and other loose ends have caused some scholars to brand the astrolabe a fake. King has since described 22 other astrolabes from fifteenth-century Vienna, which he believes validate this one (although not all his critics are convinced).

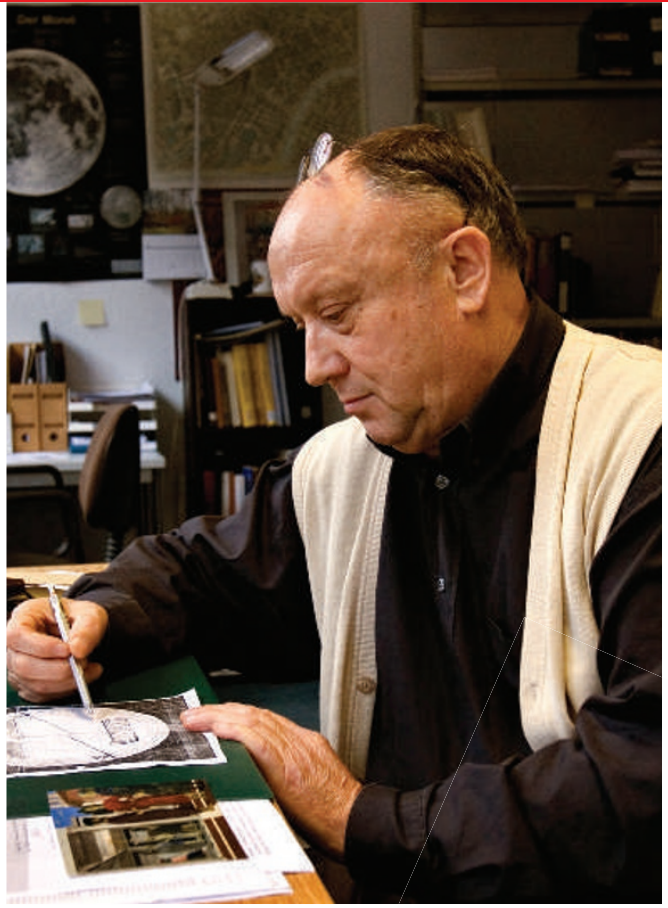

Bessarion, I arise in Rome in 1462 as a work of Johannes explaining the rotation of the universe," which is reminiscent of the Greek inscription on the Byzantine astrolabe.

It is the sort of puzzle that Bessarion would have appreciated, says King, and that the brilliant Regiomontanus was perfectly placed to devise. The mystery of the imperfect couplet thus apparently solved, King and Holzschuh wrote a paper on the topic. But when King went to Holzschuh with the finished manuscript, the engineer had another surprise for him.

In researching Bessarion, Holzschuh discovered that the cardinal had been proposed as the bearded figure in The Flagellation, and he Berthold Holzschuh deciphered hidden meanings in the inscription on the back of a fifteenth-century astrolabe (below).

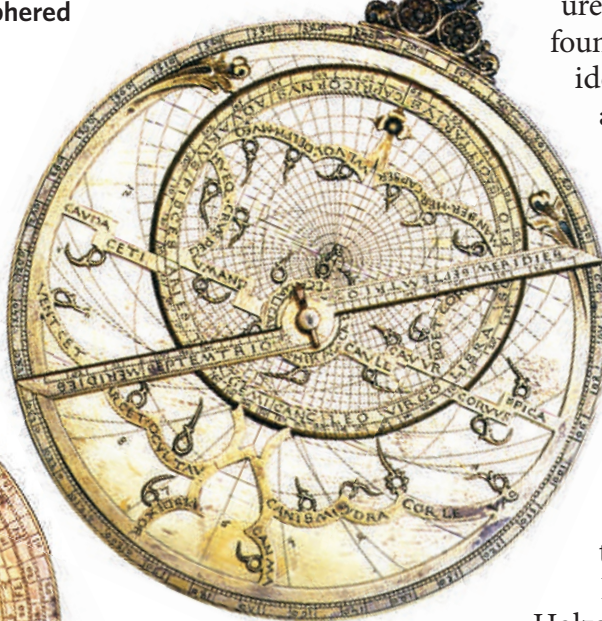
identified in the inscription also appear in interpretations of the picture. $\mathrm{He}$ made an enlarged photocopy of the inscription, the same width as the painting, and laid it underneath (see graphic overleaf). Names in the poem started to line up with the appropriate figures. Could it provide a key to the painting?

King has since extended Holzschuh's findings into a 300page book intended for publication

None of these other astrolabes has an inscription, however. Early in 2005, King asked a mature student, Berthold Holzschuh, to study the inscription for a seminar at the Frankfurt institute. A wood-construction engineer, Holzschuh is fluent in Greek and Latin, and has a long-standing interest in astrolabes.

$\mathrm{He}$ turned up at the seminar beaming. $\mathrm{He}$ had spotted names and meanings hidden within the inscription, which explained why the couplet was so oddly arranged.

A date referring to the original Byzantine astrolabe, 1062, can be found in the lower right of the inscription, using the IO from IOANNIS, perhaps explaining why Regiomontanus split that word. Reading down the left-hand side, Holzschuh noticed the phrase SVB CD ANNIS - 'at 400 years' - which would refer to the anniversary of the Byzantine astrolabe. And reordering the words in the inscription produced the message: "Under the protection of this year. He looked for clusters of letters suggesting names that would have been important to Bessarion, and found they fell into eight vertical groupings across the inscription: "We tried other combinations but they didn't work." King concluded that the eight vertical groupings correspond to the eight figures in the painting.

\section{Cryptic crossword}

For the figures on the left, King finds clusters of letters suggesting Latin names that roughly agree with previously proposed identities. For the man on the throne, King picks out references to Ioannis VIII and Herod, as well as the word SEDES, meaning throne, and suggesting Pontius Pilate. For the man being whipped, he identifies references to Christ and the Church, and for the turbanned figure, names suggesting the Ottoman sultan and Herod again.

For the two figures whipping Christ, King associates the man on the right with Herod, Pontius Pilate and Caesar. But for the man on the left, King sees the letters IVDAEUS - suggesting Judas. This identity has not been taken 
seriously before, but King says it is supported by the painting itself, which has the figure reaching out and touching Christ: "Judas Iscariot was the disciple close enough to touch Jesus," he says. Another name that occurs is George of Trebizond, with whom Bessarion had a long-running scholarly feud.

So which identity is correct for each figure? This is where King's interpretation departs fundamentally from previous attempts. He argues that there is not just one identity intended for each man, but several, explaining why it has been so difficult to assign the figures to any one person. Like the poem, the painting conceals multiple meanings, depending on

\section{出 how it is read.}

Once King was satisfied that the poem matched up with the flagellation scene, he turned his attention to the men on the right. For the bearded figure, King sees the name Bessarion. For the angelic youth, he sees Regiomontanus, and also the names of three talented young men who had been close to Bessarion but were felled by disease - his dead godson Buonconte and two of his friends' sons, Bernardino Ubaldini and Vangelista Gonzaga. Bessarion transferred all his lost hopes for these young scholars to the promising Regiomontanus, says King. The man on the right is associated with three people: the nobleman Giovanni Bacci, previously suggested as a possible sponsor for the painting, Bernardino's father and Vangelista's adoptive father.

\section{Multiple identities}

King believes that subtle clues in the painting confirm his interpretation. For example, the angelic face of the young man in red is explained by the dead youths. And the gown of the figure on the right is embroidered with thistles, perhaps hinting at dalla Carda, the name of Bernadino's father (the Italian for thistle is cardo), and holds purse strings, hinting at the sponsor, Bacci.

According to King, many times, events and people are overlaid in one frozen scene. The painting represents not just the flagellation of Christ, but what Bessarion saw as the betrayal of the Eastern Church. It also serves as a consolation for the lost young men, and celebrates the arrival of Regiomontanus. And it demonstrates just how far it is possible to go with the concept described in the painting's enigmatic

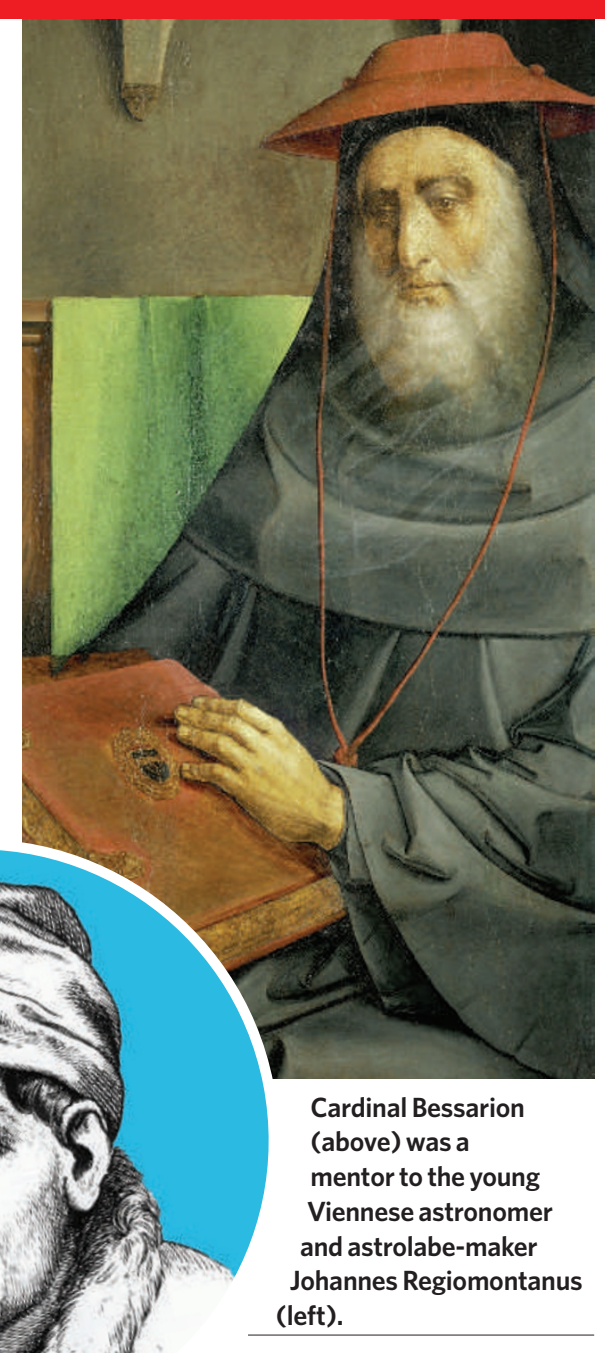

original title: "They came together in one."

King suggests that when Regiomontanus conceived the inscription, he added a few concealed meanings, mostly relating to the older astrolabe, which he thought would amuse his teacher. But as Bessarion studied the letters, he may have seen other chance combinations - you can see anything in this kind of puzzle if you look hard enough — that meant something to him, and so the idea for a painting may have emerged. Transferring the hidden identities into a painting would have been the ultimate representation of Bessarion's feelings about his life and the Church.

There is no direct evidence that Bessarion commissioned the painting from Piero, but they were

"No art
historian has
looked at the
geometry of
the painting."
- David King
known to each other (Bessarion is featured in Piero's most famous work, the wall frescoes at Arezzo). And there are several occasions at around the right time when they may have been in the same town.

So how do we know that King is not just seeing what he wants to see, as he believes Bessarion once did? Beyond the hidden characters he has identified in the painting, King says his evidence connecting the astrolabe and the painting is mathematical.
According to King, the epigram and the painting both hint at a ratio called the 'divine proportion' or 'golden ratio', which is aesthetically pleasing. It describes a line divided such that the ratio of the lengths of the two sections $(\mathrm{A}: \mathrm{B})$ is the same as the ratio between the whole line and the larger section $(\mathrm{A}+\mathrm{B}$ : A). The current view among art historians is that although the ratio was known during the Italian Renaissance, there is no evidence that Piero, or anyone else, used it in their art.

Regiomontanus would have been familiar with the divine proportion from his studies of the geometry of Euclid, and King believes that the dates of the two astrolabes (1062 and 1462), which cut their centuries roughly in the divine proportion, may have reminded him of it.

In King's interpretation, the eight vertical groupings in the poem match the geometry of the painting by lining up with the eight figures. King identifies two vertical lines at $3 / 8$ and 5/8 of the inscription's width, drawn through the B and the I of BESSARION (that is, his initials), which each divide the inscription in something close to the divine proportion. These match vertical lines drawn between the eyes of Christ and of the bearded figure, two important figures in the painting (see graphic, opposite).

King believes that contrary to the standard view, Piero may have used the golden ratio in his painting. The vertical line between Christ's eyes divides the flagellation scene (its edges defined by the bordering columns) almost exactly in the divine proportion. To get this effect, Piero would have had to position the observer's viewpoint very precisely, thus fixing the position of the 'vanishing point' of his carefully worked out perspective.

King is careful to describe his ideas as a "hypothesis". But he argues that his interpretation fits with what is known, and solves many of the mysteries surrounding the painting. "It's one of the most spectacular discoveries in the history of science," he says.

Many disagree. Some art historians have dismissed the idea entirely, describing it to Nature as "nonsensical", "embarrassing" and "utter rubbish". Unlike the most widely accepted interpretation of Piero's painting, by Princeton art historian Marilyn Lavin (see 'The Establishment view'), they feel King's hypothesis stretches credulity too far: if you layer enough subjective assumptions on top of each other, they argue, you can find anything you like.

Kemp is one of the more moderate voices from that community. But even he is highly sceptical about any link between the astrolabe 
and the painting. "It requires a substantial leap of faith," he says. "What is the concrete reason

There is more enthusiasm for King's ideas outside the art-history community. João Pedro Xavier, an architect and geometrician in Porto, Portugal, who has studied Piero, finds King's measurements persuasive. Piero wrote extensively about the divine proportion in his mathematical work on regular polyhedrons, Xavier notes, and it follows naturally from his work with perspective. "He knew these relations, he could do it almost exactly." And if Piero was going to use the divine proportion anywhere in his art, "the person to put in such a position is Christ". Of course there is no evidence that Piero intended this golden ratio, but for a painting that has been so intensively studied, "why did nobody notice this before?" Xavier says. "It is strange."

\section{Divided opinion}

Neil Graves, a professor of English at the University of Tennessee in Knoxville and an expert in hidden meanings in literary texts, says that in the absence of direct evidence of what an author intended, it is necessary to consider factors such as whether a practice was common at the time, and how likely it is to have occurred by chance.

He is taken with King's and Holzschuh's reading of the astrolabe inscription, and agrees for making the connection?"

\section{The Establishment view}

The reading of Piero della Francesca's The Flagellation most generally accepted by the art world was first published by Princeton art historian Marilyn Lavin in 1968 (see Piero della Francesca: The Flagellation, Univ. Chicago Press, 1973).

As is conventional in art history, Lavin answers the questions about the painting by referring to other works of the time. She identifies the three men on the right on the basis of portraits from the same period.

She believes that the right-hand figure, in his blue and gold cloak, is Ludovico Gonzaga. The man on the left, in Byzantine attire and with the split beard of an astrologer, is the respected astrologer and Gonzaga's life-long friend, Ottaviano
Ubaldini della Carda.

Both these men had lost a son and Lavin suggests that the angelic youth between them is a memorial to an idealized 'beloved son', mirrored by the heavenly beloved son, Christ, on the far left. Lavin believes the painting was probably commissioned by Ubaldini for the ducal palace in Urbino, where he lived.

J.M. that the odd spacing was probably intentional, to allow extra meanings. Word-play and hidden readings were particularly popular during mediaeval and Renaissance times. Signatures were commonly written as clusters of letters: Christopher Columbus adopted a four-line acrostic that has never been fully decoded.

But both Xavier and Graves baulk at King's attempts to link his inscription geometrically with the painting. Both feel that it seems arbitrary to divide the painting vertically at the eyes of Christ and of the bearded figure, and to split the poem at the B and the I. Graves says that King deserves a hearing, however. "I don't think he proves his argument, but he makes an interesting and sensible case."
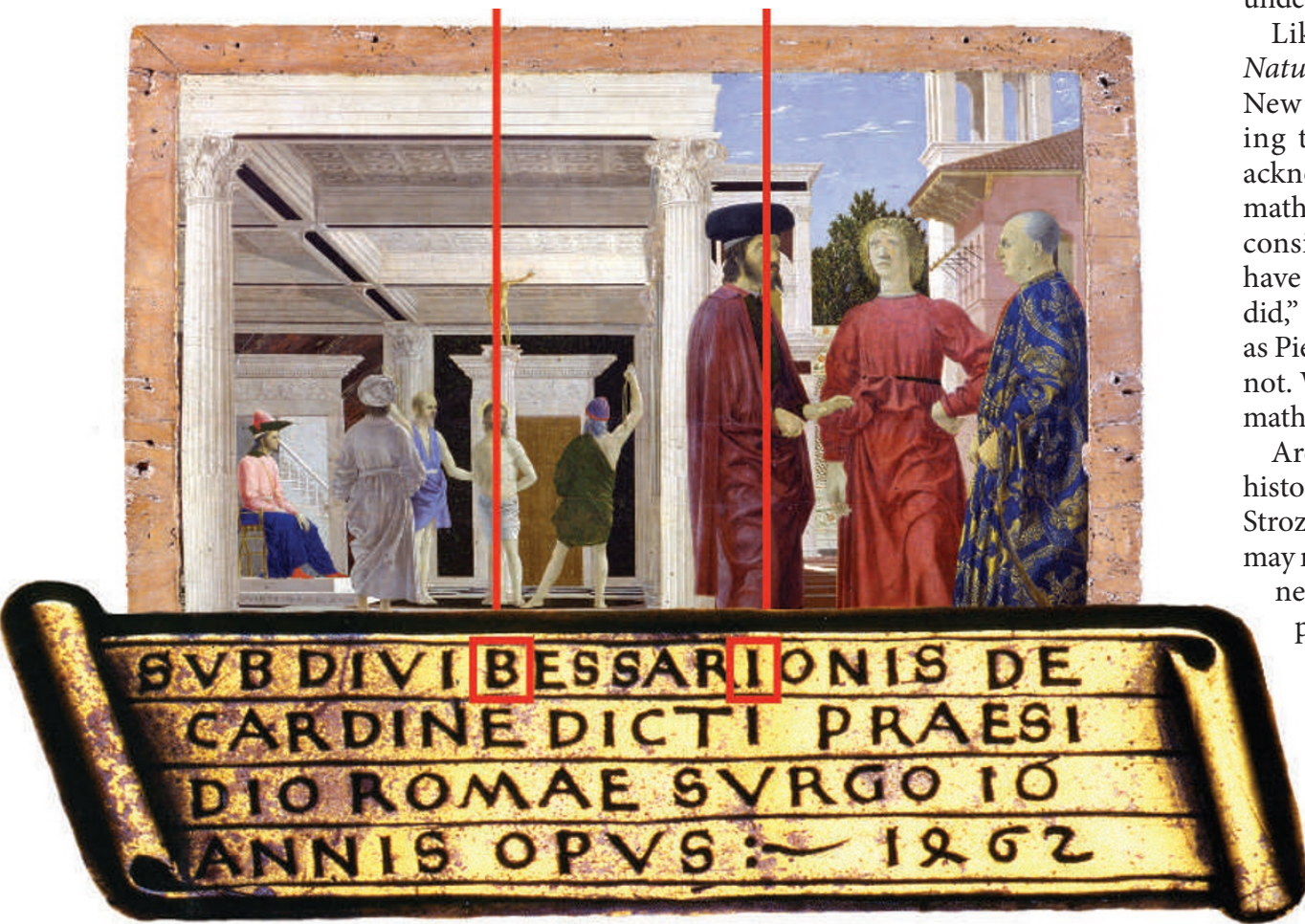

Controversial codes: King says he can line up hidden names in the couplet with figures in the painting.
King is undaunted by the criticism he has received, and believes that some art historians will dismiss his work because they can't understand it. "The epigram and painting are mathematical in nature," he says. "No art historian has ever looked at the basic geometry of the painting".

But even an expert with mathematical training, such as Kemp, says that drawing any conclusions from measurements alone is fraught with problems. Part of the difficulty is deciding what to measure and where to measure it from and to, especially on a complicated painting like The Flagellation. "You are likely to hit something," Kemp says. "I want to see direct evidence." Such evidence might be lines drawn underneath the paint.

Like other art historians approached by Nature, Ellen Handy of the City College of New York worries that King may be jumping too quickly to conclusions, but she acknowledges that art history often ignores mathematics. "Ironically, many of those who consider themselves as art historians don't have the training that the artists of the time did," she says. Many Renaissance artists, such as Piero, were skilled geometricians. "We are not. We can learn from those who have that mathematical training now."

Architect James Bradburne, also a cultural historian and director general of the Palazzo Strozzi in Florence, acknowledges that proof may never be found, but supports King's ideas nevertheless: "If this is accepted even as a plausible hypothesis, then it says that scientific objects can legitimately be treated as historical documents, in the same way as paintings themselves have been. Scientific objects can be considered part of the puzzle."

Jo Marchant is news editor for Nature. 